\title{
PENGARUH CELEBRITY ENDORSEMENT DAN CITRA MEREK TERHADAP NIAT BELI KOPI CAFFINO MELALUI SIKAP TERHADAP MEREK
}

\author{
Mirza Dwi Darmawan \\ Universitas Negeri Surabaya \\ darmawanmirza48@gmail.com \\ Sri Setyo Iriani \\ Universitas Negeri Surabaya \\ srisetyo@unesa.ac.id
}

Abstract

\begin{abstract}
The increasing level of competition in marketing requires companies to present different marketing strategies that are superior to competing companies. Caffino is a local coffee brand from Indonesia that using celebrity endorsement as marketing strategies to enhance customer purchase intention. The purpose of this paper is to analyze and discuss the effect of celebrity endorsement and brand image on purchase intention through the attitude toward brand on Caffino coffee. This type of research is quantitative research. This research uses a non-probability sampling technique. Questionnaires were distributed to 200 participants with Google form. Data analysis techniques using path analysis. The results of this study showed that there is a positive and significant effect of celebrity endorsement and attitude toward brand on purchase intention. However, the brand image had no significant effect on purchase intention. There is also a positive and significant effect of celebrity endorsement and brand image on attitude toward the brand.
\end{abstract}

Keywords: attitude toward brand; brand image; celebrity endorsement; purchase intention

\section{PENDAHULUAN}

Seiring berkembangnya zaman yang semakin modern, persaingan pemasaran produk terbilang cukup ketat. Persaingan ini dikarenakan calon konsumen yang dimudahkan oleh teknologi dapat dengan mudah mencari informasi tentang produk-produk apa yang akan dibelinya (Vidyanata \& Hadiwidjojo, 2018). Hal tersebut mengharuskan perusahaan-perusahaan untuk menampilkan strategi pemasaran yang berbeda dan lebih unggul dari perusahaan pesaing, Perusahaan-perusahaan berlomba-lomba untuk menarik atensi dari calon konsumen dengan berbagai macam strategi pemasaran, salah satunya dengan memberikan informasi tentang keunggulan produk kepada calon konsumennya lewat strategi promosi periklanan. Supaya produk yang ditawarkan pemasar lewat media iklan mempunyai daya tarik tersendiri untuk calon konsumen, maka pemasar membutuhkan dukungan dari tokoh populer maupun selebriti sebagai penyampai pesan informasi produknya ke calon konsumen sasaran melalui media promosi iklan.(Lukitaningsih, 2013)

Selebriti biasanya digunakan oleh pemasar untuk memengaruhi perilaku konsumen dalam memilih suatu produk. Selebriti merupakan orang-orang yang dikenal dengan prestasi dan ketrampilannya. Jenis selebritis biasanya terdiri dari penyanyi, aktor, atlet, atau orang yang terkenal dengan bakatnya di bidang tertentu (Restanti et al., 2019). Menurut McCracken, (1989) Selebriti endorser adalah orang yang menikmati pengakuan publik dan yang menggunakan pengakuan ini atas nama barang saat tampil dalam iklan. Selebriti diyakini dapat dengan cepat menarik perhatian calon konsumen dan membuat mereka untuk menyukai atau memilih produk yang diiklankan, sehingga apabila suatu merek atau produk diiklankan oleh orang-orang terkenal maka akan meningkatkan penjualan sehingga tercipta hubungan yang saling menguntungkan bagi para selebritis khususnya perusahaan (Ghani \& Kakakhel, 2011).

Selebriti yang memiliki kredibilitas yang baik dapat membangun niat konsumen untuk membeli suatu produk tertentu. Menurut Schiffman \& Kanuk, (2000:121) mendefinisikan niat beli sebagai perilaku transaksi yang cenderung ditunjukkan konsumen setelah mengevaluasi suatu produk, dan mengadopsi reaksi konsumen terhadap suatu produk untuk mengukur kemungkinan pembelian konsumen. 
Mirza Dwi Darmawan \& Sri Setyo Iriani. Pengaruh Celebrity Endorsment dan Citra Merek terhadap Niat Beli Kopi Caffino melalui Sikap terhadap Merek

Sehingga pemasar sangat berhati-hati dalam memilih selebriti sebagai pendukung mereknya. OseiFrimpong et al., (2019), Koththagoda \& Weerasiri, (2015), dan Apejoye, (2013) mengemukakan adanya pengaruh signifikan dari celebrity endorsement terhadap perilaku pembelian konsumen. Penggunaan celebrity endorsement dalam iklan memiliki pengaruh yang signifikan terhadap niat pembelian konsumen. Namun Jamil \& Hassan, (2014) mengemukakan endorsement melalui selebriti memiliki pengaruh yang tidak terlalu signifikan terhadap niat beli konsumen, Menurut Vidyanata \& Hadiwidjojo, (2018) endorsement selebriti terbukti tidak dapat membangkitkan niat beli secara langsung. Pemilihan sikap merek sebagai mediator dalam penelitian ini karena celebrity endorser dapat memengaruhi sikap konsumen terhadap merek secara menguntungkan (Solomon, 2011).

Citra Merek dari suatu produk yang positif akan memengaruhi niat membeli konsumen dan akan mendorong konsumen untuk melakukan pembelian (Wang \& Tsai, 2014). Menurut Surachman, (2008:13) citra merek adalah sebagian dari merek yang dapat dikenali namun tidak dapat diucapkan, seperti lambang, desain huruf, warna khusus atau persepsi pelanggan atas sebuah produk atau jasa yang diwakili oleh mereknya. Dengan terciptanya citra merek yang baik untuk suatu produk dimata konsumen akan sangat berguna bagi pemasar, karena citra merek akan memengaruhi penilaian yang diberikan konsumen terhadap merek alternatif lain yang diharapkan, tidak hanya dapat memenuhi kebutuhan konsumen, tetapi dapat memberikan kepuasan yang lebih baik dan lebih terjamin. Seperti yang dikemukakan oleh Schiffman dan Kanuk, (2000: 141), konsumen selalu memilih merek berdasarkan citranya. Isyanto et al., (2020) mengemukakan citra merek berpengaruh secara parsial terhadap niat beli konsumen. Cynthiadewi \& Hatammimi, (2014) dan Rumokoy et al., (2016) menyatakan bahwa citra merek berpengaruh positif dan signifikan terhadap niat beli. Pada saat citra merek telah terbentuk secara baik di dalam benak konsumen, maka akan muncul sikap terhadap merek tersebut. Sikap terhadap merek tersebut dapat dipengaruhi oleh citra merek dari suatu produk produk, Semakin disukai citra merek, maka semakin positif sikap terhadap produk bermerek dan atributnya (Aghekyan-Simonian et al., 2012). Menurut Phelps \& Hoy, (1996) sikap konsumen terhadap merek merupakan kecenderungan yang berfokus pada akibat yang menguntungkan ataupun tidak menguntungkan pada merek tertentu sesudah konsumen menonton iklan pada merek tersebut.

Berdasarkan data yang diperoleh dari Topbrand-award.com, (2021), terdapat 3 merek kopi bubuk instant yang terbaik dan lebih dikenal oleh masyarakat Indonesia. Produk dengan merek Good Day menempati posisi pertama dengan index sebesar 37.8\% yang kemudian disusul oleh indo café dengan index sebesar $13.6 \%$ dan di posisi terakhir terdapat Nescafe dengan index sebesar $11.5 \%$. Ketiga merek tersebut sama-sama menggunakan strategi promosi dengan menggunakan celebrity endorsement sebagai pendukung mereknya.

Tabel 1. TOP BRAND INDEX FASE 12021 KATEGORI KOPI BUBUK INSTANT

\begin{tabular}{|c|c|c|}
\hline Brand & TBI 2021 & Endorse \\
\hline Good Day & $37,8 \%$ & Selebriti (Afgan dan Maudy Ayunda) \\
\hline Indocafe & $13,6 \%$ & Selebriti (Drifter Emanuel Amandio) \\
\hline Nescafe & $11,5 \%$ & Selebriti (Nicholas Saputra) \\
\hline
\end{tabular}

Sumber: Top Brand Award (2021), data diolah

PT Sumber Kopi Prima pada tahun 2018 membuat kopi 3 in 1 instant pertama dengan kopi dan susu asli dengan nama brand Caffino. Berdasarkan data di atas, Kopi Caffino masih belum masuk dalam Top Brand Index bila dibandingkan dengan produk kopi lain yang sudah ada terlebih dahulu. Caffino juga mengikuti stratgei pemasaran yang dilakukan oleh para pesaingnya dengan menggunakan selebriti sebagai pendukung dari suatu merek. Selebriti yang dipilih oleh Caffino merupakan selebriti yang sudah sangat terkenal dikalangan anak-anak generasi milenial yaitu Iqbaal Ramdhan. Menurut Ihsan Mulia Putri selaku CEO PT Sumber Kopi Prima, Caffino memilih Iqbaal Ramadhan sebagai Brand Ambassador dikarenakan Caffino melihat kecocokan Iqbaal yang berani melakukan hal-hal yang baru dan juga karakter Iqbaal yang mempunyai idealisme di karir dan jadi diri sendiri dalam 
keseharian dianggap tepat untuk mewakili brand Caffino (Caffino.id, 2019). PT Sumber Kopi Prima juga berupaya untuk membangun citra merek yang positif dari kopi Caffino, hal tersebut bertujuan agar kopi Caffino dapat dengan mudah diingat oleh para konsumennya. Citra merek yang ingin dibentuk oleh kopi Caffino ini yaitu Caffino merupakan kopi nya anak muda yang memiliki idealisme dan bisa menjadi diri sendiri, hal tersebut sesuai dengan pemilihan Iqbal Ramadhan sebagai Brand Ambassador yang dirasa Iqbal Ramadhan dapat mencerminkan citra yang dibentuk dari merek Kopi Caffino tersebut. Penelitian ini bertujuan untuk mengetahui pengaruh celebrity endorsement dan citra merek terhadap niat beli pada kopi Caffino melalui sikap terhadap merek.

\section{KAJIAN PUSTAKA DAN PENGEMBANGAN HIPOTESIS}

\section{Celebrity Endorsement}

Menurut McCracken, (1989) selebriti endorser merupakan orang yang menikmati pengakuan publik dan yang menggunakan pengakuan ini atas nama barang saat tampil dalam iklan. Shimp, (2007:33) mendefinisakn celebrity endorser sebagai bintang televisi, aktor film, atlet terkenal, hingga individu yang sudah meninggal, yang dapat memengaruhi sikap serta perilaku konsumen pada produk yang diiklankannya. Jadi, celebrity endorsement merupakan semua individu yang menikmati pengenalan publik dan menggunakan kepopuleran tersebut untuk memengaruhi konsumen dengan tampil bersama merek produk yang mereka iklankan.

Indikator yang digunakan untuk mengukur celebrity endorsement mengadopsi dari penelitan Koththagoda \& Weerasiri, (2015) dan Gupta et al., (2015) yaitu: attractiveness (daya tarik), trustworthiness (tingkat kepercayaan), dan expertise (keahlian).

\section{Citra Merek (Brand Image)}

Menurut Surachman, (2008:13) Citra merek merupakan sebagian dari merek yang dapat dikenali namun tidak dapat diucapkan, seperti lambang, desain huruf, warna khusus atau persepsi pelanggan atas sebuah produk atau jasa yang diwakili oleh mereknya. Citra merek merupakan konsep yang diciptakan oleh konsumen karena alasan subyektif dan emosi pribadinya (Ferrinadewi, (2008:166). Jadi, Citra Merek adalah suatu persepsi dan keyakinan tentang sebuah merek yang dimiliki dan akan diingat oleh seorang konsumen.

Menurut Keller, (2013:325-335) terdapat beberapa teknik kualitatif yang digunakan untuk mengidentifikasi sumber-sumber ekuitas merek, antara lain: free association, projective techniques, Zaltman Metaphor Elication Technique (ZMET), neural research methods, brand personality and values, dan ethnograpic and experiental methods. Dalam penelitian ini, pengukuran citra merek dilakukan dengan metode free association di mana pengukuran dilakukan dengan memberikan pertanyaan kepada responden mengenai apa yang ada di benak mereka tentang sebuah produk maupun merek. Berdasarkan hasil free association yang dilakukan, kopi Caffino memiliki citra merek yang positif dalam benak konsumen, beberapa persepsi yang konsumen ungkapkan antara lain, Kopi Caffino merupakan kopinya anak muda, Kopi Caffino merupakan kopi sachet instan dengan harga yang murah, dan Kopi Caffino memiliki kemasan yang unik dibandingkan dengan merek lain

\section{Sikap terhadap Merek (Attitude toward Brand)}

Menurut Spears \& Singh, (2004:53-56) sikap terhadap merek merupakan evaluasi abadi yang mungkin memberi energi pada perilaku. Sikap terhadap merek merepresentasikan pengaruh konsumen terhadap suatu merek, yang dapat mengarah pada tindakan nyata, seperti pilihan terhadap suatu merek (Franciosa et al., 2014). Jadi, Sikap terhadap merek adalah suatu reaksi emosional individu konsumen yang merasa suka atau tidak suka terhadap suatu produk setelah konsumen tersebut melihat iklan dari produk tersebut.

Indikator yang digunakan untuk mengukur sikap terhadap merek mengadopsi dari penelitian Franciosa et al., (2014) yaitu: Merek diingat, Merek disukai, dan Merek dipilih. 
Mirza Dwi Darmawan \& Sri Setyo Iriani. Pengaruh Celebrity Endorsment dan Citra Merek terhadap Niat Beli Kopi Caffino melalui Sikap terhadap Merek

\section{Niat Beli (Purchase Intention)}

Mowen dan Minor, (2002:315) mendefinisikan niat membeli sebagai keinginan konsumen untuk berperilaku dengan cara tertentu yang bertujuan untuk memiliki, menghabiskan, dan menggunakan barang ataupun jasa. Schiffman \& Kanuk, (2000:121) mendefinisikan niat beli sebagai perilaku transaksi yang cenderung ditunjukkan konsumen setelah mengevaluasi suatu produk, dan mengadopsi reaksi konsumen terhadap suatu produk untuk mengukur kemungkinan pembelian konsumen. Niat beli adalah kecenderungan atau keinginan konsumen individu ataupun kelompok yang mendorong konsumen tersebut untuk melakukan suatu perilaku pembelian produk setelah konsumen tersebut melakukan penilaian dan evaluasi terhadap suatu produk tertentu. (Vidyanata \& Hadiwidjojo, 2018).

Indikator yang digunakan untuk mengukur niat beli mengadopsi dari penelitian Hanjani \& Widodo, (2019) dan Vidyanata \& Hadiwidjojo, (2018) dengan penyesuaian dari objek yang diteliti yaitu: transaksional, prefensial, dan eksploratif.

\section{Hubungan antar Variabel}

Menurut Osei-Frimpong et al., (2019) celebrity endorser yang memiliki atribut seperti attractiveness, trustworthiness, dan familiarity berpengaruh positif terhadap persepsi konsumen niat membeli. Koththagoda \& Weerasiri, (2015) dan Apejoye, (2013) menyatakan celebrity endorsement memiliki pengaruh yang signifikan terhadap niat pembelian konsumen. Sedangkan Jamil \& Hassan, (2014) menyatakan bahwa endorsement melalui selebriti memiliki pengaruh yang tidak terlalu signifikan terhadap niat beli konsumen. Vidyanata \& Hadiwidjojo, (2018) dan Stephanie et al., (2013) menyatakan celebrity endorsement terbukti tidak bepengaruh secara langsung terhadap niat beli.

\section{H1: Terdapat pengaruh celebrity endorsement terhadap niat beli.}

Penggunaan celebrity endorsement dalam mendukung suatu merek dapat memengaruhi sikap konsumen terhadap merek, kredibilitas dan daya tarik yang dimiliki oleh seorang selebriti dapat digunakan oleh pemasar untuk membentuk sikap yang positif terhadap suatu produk. Menurut Vidyanata \& Hadiwidjojo, (2018) konsumen menganggap bahwa endorser dari suatu merek lebih kredibel dapat membuat sikap mereka terhadap merek yang didukung akan menjadi lebih positif. Ha \& Lam, (2017) dan Vien et al., (2017) menunjukkan bahwa sikap konsumen terhadap merek dipengaruhi secara positif oleh celebrity endorsement.

H2: Terdapat pengaruh celebrity endorsement terhadap sikap terhadap merek.

Citra merek dari suatu produk yang positif akan memengaruhi niat membeli konsumen dan akan mendorong konsumen untuk melakukan pembelian (Wang \& Tsai, 2014). Menurut Isyanto et al., (2020) citra merek berpengaruh secara parsial terhadap niat beli konsumen. Cynthiadewi \& Hatammimi, (2014) dan Rumokoy et al., (2016) menyatakan bahwa citra merek berpengaruh positif dan signifikan terhadap niat beli.

H3: Terdapat pengaruh citra merek terhadap niat beli.

Sikap terhadap merek dapat dipengaruhi oleh citra merek dari suatu produk, Semakin disukai citra merek, maka semakin positif sikap terhadap produk bermerek dan atributnya (Aghekyan-Simonian et al., 2012). Manurut Elseidi \& El-Baz, (2016) dan Ain \& Ratnasari, (2015) citra merek berpengaruh positif dan signifikan terhadap sikap konsumen terhadap merek.

H4: Terdapat pengaruh citra merek terhadap sikap terhadap merek.

Semakin baik sikap konsumen terhadap suatu merek tertentu, maka semakin besar juga pengaruh perilaku konsumen saat memilih suatu produk. Menurut Ha \& Lam, (2017) dan Vidyanata \& Hadiwidjojo, (2018) sikap konsumen terhadap merek secara signifikan memiliki pengaruh positif 
terhadap niat membeli. Singh \& Banerjee, (2018) menunjukkan bahwa adanya hubungan positif antara sikap terhadap merek dan niat beli, yang menyimpulkan bahwa sikap terhadap merek meningkatkan niat beli di kalangan konsumen karena motivasi mereka meningkat.

H5: Terdapat pengaruh sikap terhadap merek terhadap niat beli.

\section{METODE PENELITIAN}

Penelitian ini merupakan penelitian kuantitatif. Jenis penelitiannya adalah penelitian konklusif yang bertujuan untuk menguji hipotesis dan hubungan antar variabel. Menggunakan pendekatan kausal untuk memahami variabel mana yang memengaruhi variabel bebas (celebrity endorsement \& citra merek) dan variabel mana yang merupakan sebuah akibat (sikap terhadap merek \& niat beli). Data yang digunakan dalam penelitian ini adalah data primer berupa hasil jawaban angket dan data sekunder menggunakan penelitian terdahulu. Variabel bebas yang terdapat pada penelitian ini adalah celebrity endorsement dan citra merek, dan variabel mediasinya adalah sikap terhadap merek, sedangkan variabel terikat dalam penelitian ini adalah niat beli. Dalam penelitian ini responden berjumlah 200 orang. Populasi penelitian ini adalah calon konsumen Kopi Caffino yang pernah melihat iklan Caffino yang dibintangi Iqbaal Ramadhan, dengan karakteristik calon konsumen berusia 17-40 tahun, yang mengikuti media sosial dari kopi Caffino. Teknik pengumpulan data menggunakan angket kuesioner yang didistribusikan secara online melalui google form yang disebar melalui media sosial Whatsapp, Twitter, dan Instagram.

Teknik pengambilan sampel dalam penelitian ini menggunakan teknik nonprobability sampling dengan menggunakan teknik judgemental sampling sesuai dengan karakteristiknya kemudian dilakukan uji validitas dan reliabilitas terhadap instrumen penelitian yang akan digunakan. Pengukuran yang dipilih untuk penelitian ini adalah skala likert. Data yang terkumpul dianalisis dengan path analysis (analisis jalur).

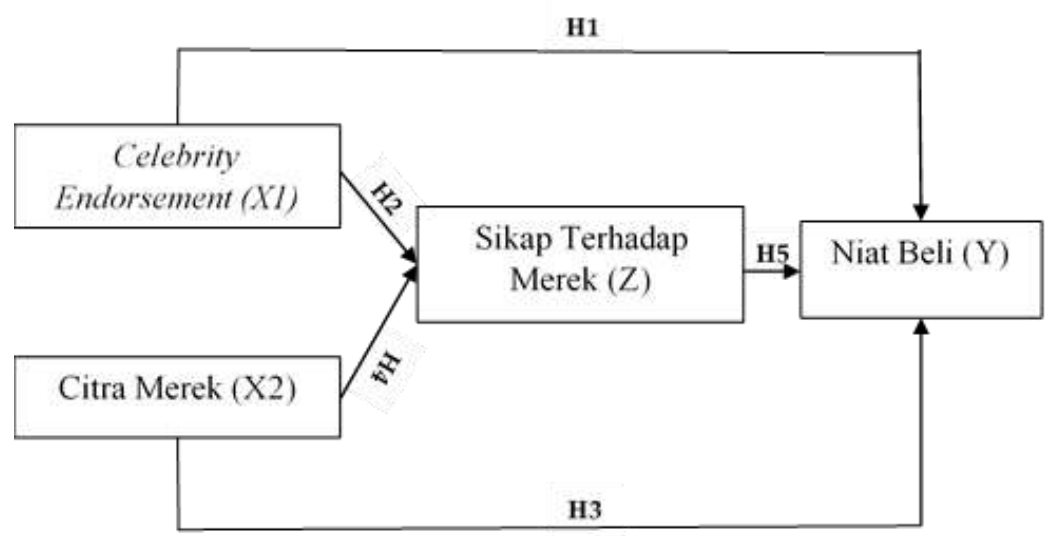

Gambar 1. KERANGKA KONSEPTUAL

\section{HASIL DAN PEMBAHASAN}

\section{Karakteristik Responden}

Tabel 2 menunjukkan bahwa dalam penelitian ini terdapat 200 responden dari pengikut media sosial kopi Caffino yang sebagian besar adalah perempuan sebanyak 124 orang (62\%), dengan usia 17-24 tahun $(76 \%)$, dengan pendidikan terakhir SMA/SMK (64,5\%), dan memiliki penghasilan <Rp. 1.500.000 (62\%), Dari Tabel 2 secara keseluruhan dapat disimpulkan bahwa sebagian besar pengikut media sosial dari kopi Caffino berjenis kelamin Perempuan dengan usia sekitar 17-24 tahun yang 
Mirza Dwi Darmawan \& Sri Setyo Iriani. Pengaruh Celebrity Endorsment dan Citra Merek terhadap Niat Beli Kopi Caffino melalui Sikap terhadap Merek

belum memiliki penghasilan tetap karena responden tersebut memiliki pendidikan terakhir SMA/SMK atau sedang berstatus mahasiswa. Hal tersebut dikarenakan kebanyakan pengikut media sosial kopi Caffino merupakan penggemar dari Iqbaal Ramadhan yang berjenis kelamin perempuan dari generasi milenial sehingga membuat mereka menjadi tertarik dan memiliki niat untuk membeli kopi Caffino karena terpengaruh oleh seorang Iqbaal Ramadhan.

Tabel 2.

\section{KARAKTERISTIK RESPONDEN}

\begin{tabular}{lcc}
\hline \multicolumn{1}{c}{ Karakteristik Responden } & Jumlah & Persentase \\
\hline Jenis Kelamin & & \\
Laki-Laki & 76 & $38 \%$ \\
Perempuan & 124 & $62 \%$ \\
Usia & & \\
17-24 Tahun & 152 & $76 \%$ \\
25-32 Tahun & 45 & $22,5 \%$ \\
33-40 Tahun & 3 & $1,5 \%$ \\
Pendidikan Terakhir & & \\
SMP & 10 & $5 \%$ \\
SMA / SMK & 129 & $64,5 \%$ \\
D3 / D4 / S1 & 61 & $30,5 \%$ \\
Penghasilan & & \\
< Rp. 1.500.000 & 124 & $62 \%$ \\
Rp. 1.500.000 - Rp. 3.000.000 & 39 & $19,5 \%$ \\
Rp. 3.100.000 - Rp. 5. 000.000 & 19 & $9,5 \%$ \\
> Rp. 5.000.000 & 18 & $9 \%$ \\
\hline
\end{tabular}

Sumber: Data diolah

\section{Hasil Uji Validitas dan Reliabilitas}

Sebelum penelitian dilakukan, terlebih dahulu data diuji validitas dan realibilitasnya. Uji validitas dan Reliabilitas pada penelitian ini dilakukan dengan cara menyebarkan kuesioner kepada 30 responden. Hasil uji validitas menunjukkan bahwa 8 item pernyataan kuesioner variabel celebrity endorsement, 7 item pernyataan kesioner variabel citra merek, 7 item pernyataan kuesioner variabel sikap terhadap merek, dan 7 item pernyataan kesioner variabel niat beli terbilang valid karena nilai R-hitung $\geq 0,361$ dan bertanda positif sehingga item-item kuesioner tersebut dapat digunakan untuk melakukan pengukuran pengaruh celebrity endorsement dan citra merek terhadap niat membeli melalui sikap terhadap merek. Selain itu, hasil uji reliabilitas menunjukkan bahwa nilai cronbach's alpha variabel celebrity endorsement bernilai 0,896 ; variabel citra merek bernilai 0,792 ; variabel sikap terhadap merek bernilai 0,912 ; dan variabel niat beli bernilai 0,874 sehingga variabel-variabel tersebut telah memenuhi syarat reliabel dengan hasil cronbach's alpha lebih besar dari 0,70 yang menunjukkan bahwa pernyataan yang dibuat pada instrumen penelitian ini adalah reliabel dan dapat digunakan sebagai alat ukur.

\section{Hasil Uji Asumsi Klasik}

Pada penelitian ini data yang terkumpul dianalisis menggunakan path analysis di mana data yang digunakan harus berdistribusi normal untuk menghindari bias dalam analisis data. Apabila data mempunyai nilai c.r (critical ratio) multivariat dalam interval $-2,58<$ critical ratio $<2,58$ maka data tersebut dinyatakan normal. Nilai uji normalitas multivariat yang didapatkan yaitu sebesar $-0,856$ (termasuk dalam interval $\pm 2,58$ ). Maka dapat diasumsikan bahwa data telah berdistibusi normal, sehingga dapat dilakukan uji selanjutnya. Uji outlier dilakukan untuk mendeteksi adanya multivariat outlier yang dilihat dari nilai mahalanobis distance. Nilai mahalanobis $d$-squared tidak ada yang lebih besar dari nilai critical value of chi square 0,001 dengan $\mathrm{dF}$ sebesar 4 yaitu $\mathrm{X}=18,467$ dan $\mathrm{p} 1<$ 0,01 dan nilai $\mathrm{p} 2<0,05$. Uji asumsi multikolinieritas dilakukan untuk mengetahui apakah ada hubungan linier atau korelasi antara masing-masing variabel independen dalam model. Hasil analisis 
menunjukkan bahwa tidak adanya indikasi multikolinieritas. Hal ini dapat dilihat dari nilai determinasi matriks kovarians yaitu sebesar 17648,161 yang jauh dari nilai nol. Jadi dalam penelitian ini tidak terdapat masalah multikolinieritas.

\section{Hasil Analisis Path}

Uji kelayakan model dapat dilihat dari nilai koefisien determinasi (squared multiple correlations). Uji tersebut menunjukkan besarnya pengaruh (kontribusi) variabel eksogen terhadap variabel endogen. Hasil analisis menunjukkan bahwa kontribusi variabel celebrity endorsement dan citra merek terhadap sikap terhadap merek sebesar 51,3\%. Sedangkan kontribusi variabel celebrity endorsement, citra merek dan sikap terhadap merek terhadap niat membeli sebesar $65,8 \%$.

Berdasarkan pada persamaan path yang dilihat dari output standardized regression weights menunjukkan terdapat pengaruh positif pada variabel celebrity endorsement terhadap sikap terhadap merek dengan nilai koefisien jalur sebesar 0,191. Hal ini menunjukkan bahwa semakin baik selebrity endorser yang digunakan oleh kopi Caffino maka sikap konsumen yang terbentuk terhadap kopi Caffino akan semakin baik juga. Selanjutnya variabel citra merek terhadap sikap terhadap merek yang menunjukkan pengaruh positif dengan nilai koefisien jalur sebesar 0,576 yang bermakna bahwa semakin bagus citra merek kopi Caffino di benak konsumen maka sikap konsumen terhadap kopi Caffino juga akan semakin meningkat. Pengaruh variabel citra merek terhadap niat beli menunjukkan pengaruh positif dengan nilai koefisien jalur sebesar 0,073. Hal ini menunjukkan semakin bagus citra merek kopi Caffino maka semakin besar pula keinginan konsumen untuk membeli kopi Caffino. Kemudian pengaruh positif variabel selebriti endorser terhadap variabel niat beli dengan nilai koefisien jalur sebesar 0,238 artinya semakin baik selebrity endorser yang digunakan oleh kopi Caffino maka semakin meningkat pula keinginan konsumen untuk membeli kopi Caffino. Selanjutnya terdapat pengaruh positif variabel sikap terhadap merek terhadap variabel niat membeli dengan nilai koefisien jalur sebesar 0,593 yang bermakna bahwa semakin baik sikap konsumen terhadap merek kopi Caffino maka niat membeli konsumen terhadap kopi Caffino akan semakin meningkat juga. Diagram jalur pada penelitian ini ditunjukkan pada Gambar 2. Model diagram jalur pada Gambar 2. dapat dikonversi ke dalam persamaan model struktural (1) dan (2).

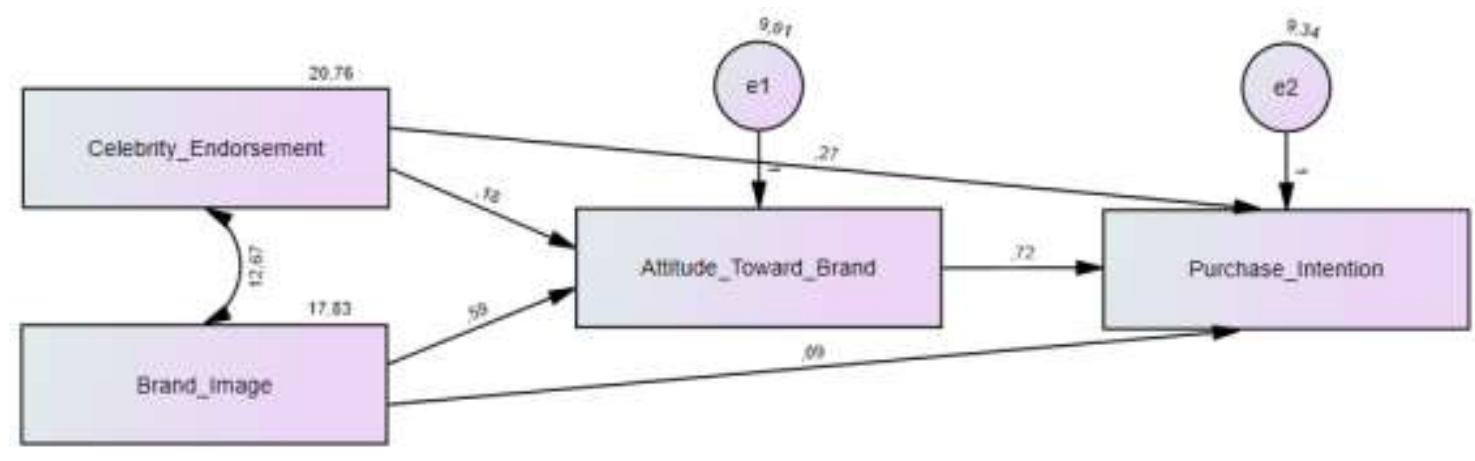

Sumber: Data AMOS

Gambar 2. DIAGRAM JALUR

$$
\begin{aligned}
& \mathrm{Z}=\mathrm{b}_{2} \mathrm{X}_{1}+\mathrm{b}_{4} \mathrm{X}_{2}+\mathrm{e}_{1}=0,18 \mathrm{X}_{1}+0,59 \mathrm{X}_{2}+9,01 \ldots \ldots \ldots \ldots \ldots \ldots \ldots \ldots \ldots \ldots \ldots \ldots \ldots \ldots \ldots \\
& \mathrm{Y}=\mathrm{b}_{1} \mathrm{X}_{1}+\mathrm{b}_{3} \mathrm{X}_{2}+\mathrm{b}_{5} \mathrm{Z}+\mathrm{e}_{2}=0,27 \mathrm{X}_{1}+0,09 \mathrm{X}_{2}+0,72 \mathrm{Z}+9,34
\end{aligned}
$$

Selanjutnya dilakukan uji hipotesis yaitu dengan membandingkan probabilitas signifikansi (p) dengan taraf signifikansi $(\alpha=0,05)$. Hipotesis dapat diterima apabila nilai probabilitas signifikansi $(\mathrm{p})$ memiliki lebih kecil dari nilai taraf signifikansi $(0,05)$. Berdasarkan Tabel 2 diperoleh bahwa H1, H2, $\mathrm{H} 4$, dan H5 diterima karena memiliki nilai C.R. hitung $\geq 2,00$ dan nilai signifikansi $(\mathrm{P}) \leq 0,05$. Sedangkan H3 ditolak karena C.R. hitung $\leq 2,00$, dan nilai signifikansi $(\mathrm{P}) \geq 0,05$. 
Mirza Dwi Darmawan \& Sri Setyo Iriani. Pengaruh Celebrity Endorsment dan Citra Merek terhadap Niat Beli Kopi Caffino melalui Sikap terhadap Merek

Hipotesis pertama mengenai hubungan celebrity endorsement terhadap niat beli. Tabel 3 menunjukkan nilai C.R. hitung sebesar 4,226>2,00 dan nilai probabilitas sebesar *** yang artinya kurang dari $0,001(\mathrm{p} \leq 0,05)$ sehingga hipotesis pertama diterima, yang artinya variabel celebrity endorsement berpengaruh signifikan terhadap niat beli konsumen kopi Caffino.

Tabel 3.

\section{HASIL UJI HIPOTESIS}

\begin{tabular}{lccccc}
\hline \multicolumn{1}{c}{ Hipotesis } & Variabel & Estimate & S.E. & C.R. & P \\
\hline H1 (Diterima) & celebrity endorsement $\rightarrow$ niat beli &, 272 &, 064 & 4,226 & $* * *$ \\
H2 (Diterima) & celebrity endorsement $\rightarrow$ sikap terhadap merek &, 180 &, 062 & 2,906 &, 004 \\
H3 (Ditolak) & citra merek $\rightarrow$ niat beli &, 090 &, 080 & 1,127 &, 260 \\
H4 (Diterima) & citra merek $\rightarrow$ sikap terhadap merek &, 586 &, 067 & 8,758 & $* * *$ \\
H5 (Diterima) & sikap terhadap merek $\rightarrow$ niat beli &, 720 &, 072 & 9,981 & $* * *$ \\
\hline
\end{tabular}

Sumber: Output AMOS, data diolah

Hipotesis kedua, hubungan celebrity endorsement terhadap variabel sikap terhadap merek. Tabel 3 menunjukkan nilai C.R. hitung sebesar 2,906 > 2,00 dan nilai probabilitas sebesar $0,004(\mathrm{p} \leq 0,05)$ sehingga hipotesis kedua diterima, yang artinya variabel celebrity endorsement berpengaruh signifikan terhadap sikap konsumen terhadap merek kopi Caffino.

Hipotesis ketiga, hubungan citra merek terhadap niat beli. Tabel 3 menunjukkan nilai C.R. hitung sebesar 1,127 <2,00 dan nilai probabilitas sebesar 0,260 ( $\mathrm{p} \geq 0,05)$ sehingga hipotesis ketiga tidak diterima, yang artinya variabel citra merek tidak berpengaruh signifikan terhadap niat beli konsumen kopi Caffino.

Hipotesis keempat, hubungan citra merek terhadap variabel sikap terhadap merek. Tabel 3 menunjukkan nilai C.R. hitung sebesar 8,758 > 2,00 dan nilai probabilitas sebesar *** yang artinya kurang dari $0,001(\mathrm{p} \leq 0,05)$ sehingga hipotesis keempat diterima, yang artinya variabel citra merek berpengaruh signifikan terhadap sikap konsumen terhadap merek kopi Caffino.

Hipotesis kelima, hubungan variabel sikap terhadap merek terhadap niat beli. Tabel 3 menunjukkan nilai C.R. hitung sebesar 9,981>2,00 dan nilai probabilitas sebesar *** yang artinya nilai probabilitas lebih kecil dari $0,001(\mathrm{p} \leq 0,05)$ sehingga hipotesis kelima diterima, artinya variabel sikap terhadap merek berpengaruh signifikan terhadap niat beli konsumen kopi Caffino.

Setelah uji hipotesis, uji selanjutnya adalah uji mediasi menggunakan Sobel test. Berdasarkan hasil uji Sobel dalam penelitian ini, hasil Z sobel lebih besar dari 1,96. Sehingga dapat dikatakan bahwa terjadi pengaruh mediasi antara celebrity endorsement (X1) terhadap niat beli (Y) melalui sikap terhadap merek (Z) dan terjadi pengaruh mediasi antara citra merek (X2) terhadap niat beli (Y) melalui sikap terhadap merek $(\mathrm{Z})$.

Rata-rata tertinggi jawaban responden pada variabel celebrity endorsement terdapat pada indikator attractiveness dengan item pernyataan "Iqbaal Ramadhan tampil menggunakan pakaian yang elegan dalam iklan Caffino" yang hasil nilainya masuk dalam kategori sangat setuju. Artinya responden melihat daya tarik dari Iqbaal Ramadhan menggunakan pakaian elegen yang mencerminkan kualitas dari kopi Caffino.

Kemudian, rata-rata tertinggi jawaban responden pada variabel citra merek terdapat pada indikator favorability dengan item pernyataan "Kopi Caffino merupakan kopi sachet instan dengan harga yang murah" yang hasil nilainya masuk dalam kategori sangat setuju. Artinya responden ketika mendengar kopi Caffino mereka memikirkan tentang kopi sachet instan dengan harga yang murah, dikarenakan harga kopi Caffino terbilang cukup terjangkau bagi kalangan generasi milenial. 
Selanjutnya, rata-rata tertinggi jawaban responden pada variabel sikap terhadap merek terdapat pada indikator merek dipilih dengan item pernyataan "Saya memilih kopi Caffino karena mudah saya dapatkan di toko-toko terdekat maupun secara online" yang hasil nilainya masuk dalam kategori setuju. Artinya responden lebih memilih kopi Caffino dibandingkan merek kopi lain karena kopi Caffino mudah didapatkan di toko-toko sekitar di dekat rumah mereka, sehingga responden memiliki niat untuk membeli kopi Caffino

Rata-rata tertinggi jawaban responden pada variabel niat beli terdapat pada indikator transaksional dengan item pernyataan "Saya akan membeli kopi Caffino" yang hasil nilainya masuk dalam kategori setuju. Artinya responden memiliki keinginan untuk membeli kopi Caffino setelah responden tersebut melihat iklan dari Caffino yang dibintangi oleh Iqbaal Ramadhan. Hal tersebut dapat memengaruhi sikap responden terhadap kopi Caffino dan membuat responden berniat untuk membeli kopi Caffino.

\section{Pengaruh Celebrity Endorsement terhadap Niat Beli Kopi Caffino}

Berdasarkan hasil path analisis yang telah dilakukan, penelitian ini menunjukkan bahwa variabel celebrity endorsement berpengaruh positif signifikan terhadap variabel niat beli konsumen kopi Caffino. Hal tersebut menunjukkan semakin baik celebrity endorsement yang digunakan oleh Kopi Caffino maka akan semakin besar pula niat konsumen untuk membeli kopi Caffino. Berdasarkan hasil tersebut maka hipotesis pertama diterima. Selebriti endorser yang digunakan oleh kopi Caffino merupakan selebriti yang banyak diidolakan oleh generasi milenial yaitu Iqbaal Ramadhan, Iqbaal sendiri terbilang cukup terkenal di Indonesia berkat aktingnya yang cukup baik dalam film series Dilan. Melihat hal tersebut akhirnya Caffino memilih Iqbaal Ramadhan sebagai Brand Ambassador kopi Caffino. Berdasarkan hasil survei penelitian, calon konsumen dari kopi Caffino kebanyakan berjenis kelamin perempuan dengan usia sekitar 17-24 tahun yang belum memiliki penghasilan tetap, kebanyakan dari calon konsumen kopi Caffino dipengaruhi oleh sosok Iqbaal Ramadhan yang mampu memengaruhi para penggemarnya untuk membeli kopi Caffino, dengan harga Caffino yang murah hal tersebut sesuai dengan target pasar yang dibidik oleh Caffino.

Hasil penelitian ini sesuai dengan penelitian Osei-Frimpong et al., (2019) yang menunjukkan celebrity endorser berpengaruh positif terhadap persepsi konsumen niat membeli. Kemudian Koththagoda \& Weerasiri, (2015) mengemukakan celebrity endorsement berdampak signifikan terhadap peningkatan niat beli. Selain itu, Apejoye, (2013) juga menyatakan celebrity endorsement dalam iklan memiliki pengaruh yang signifikan terhadap niat pembelian konsumen.

\section{Pengaruh Celebrity Endorsement terhadap Sikap pada Merek Kopi Caffino}

Berdasarkan hasil path analisis yang telah dilakukan, penelitian ini menunjukkan bahwa variabel celebrity endorsement berpengaruh positif signifikan terhadap variabel sikap konsumen terhadap merek kopi Caffino. Hal tersebut menunjukkan semakin baik celebrity endorsement yang digunakan oleh Kopi Caffino maka akan semakin baik pula sikap konsumen terhadap merek kopi Caffino. Berdasarkan hasil tersebut maka hipotesis kedua diterima. Selebriti yang digunakan Kopi Caffino terbukti dapat membentuk sikap konsumen menjadi lebih positif terhadap merek kopi Caffino, konsumen menjadi mudah mengingat kopi Caffino dibanding merek lain. Berdasarkan hasil survei penelitian, kebanyakan konsumen akan mengingat merek Kopi Caffino ketika konsumen tersebut melihat Iqbaal Ramadhan muncul di TV maupun media sosial, konsumen akan secara sadar mengingat merek kopi Caffino yang dibintanginya.

Hasil penelitian ini sesuai dengan penelitian Vidyanata \& Hadiwidjojo, (2018) yang menunjukkan konsumen menganggap bahwa endorser dari suatu merek lebih kredibel dapat membuat sikap mereka terhadap merek yang didukung akan menjadi lebih positif. Selain itu, Ha \& Lam, (2017) menunjukkan bahwa sikap konsumen terhadap merek dipengaruhi secara positif oleh celebrity endorsement. Begitu juga dengan Vien et al., (2017) yang menunjukkan celebrity endorser berpengaruh positif signifikan terhadap brand attitude 
Mirza Dwi Darmawan \& Sri Setyo Iriani. Pengaruh Celebrity Endorsment dan Citra Merek terhadap Niat Beli Kopi Caffino melalui Sikap terhadap Merek

\section{Pengaruh Citra Merek terhadap Niat Beli Kopi Caffino}

Berdasarkan hasil path analisis yang telah dilakukan, penelitian ini menunjukkan bahwa variabel citra merek tidak berpengaruh positif signifikan terhadap variabel niat beli konsumen Kopi Caffino. Meskipun citra merek Kopi Caffino meningkat atau menurun hal tersebut tidak memengaruhi niat konsumen untuk membeli Kopi Caffino. Berdasarkan hasil tersebut maka hipotesis ketiga ditolak. Citra merek yang ingin dibentuk oleh kopi Caffino sendiri yaitu Caffino merupakan kopi nya anak muda yang memiliki idealisme dan bisa menjadi diri sendiri, hal tersebut sesuai dengan slogan dari kopi Caffino sendiri yaitu \#BeAuthentic karena kopi Caffino dibuat dengan kopi dan susu asli. Selain itu, Caffino juga ingin menyebarkan semangat positif kepada masyarakat luas untuk berani menunjukkan jati dirinya dan tidak hanya ikut-ikutan dengan apa yang ada di media sosial. Namun Citra tersebut belum tertangkap di benak konsumen yang kebanyakan perempuan dengan usia sekitar 17-24 tahun dikarenakan Caffino sendiri merupakan pendatang baru di kategori kopi bubuk instan yang berdiri pada tahun 2018, hal tersebut membuat citra dari kopi Caffino belum dapat memengaruhi niat beli konsumen terhadap Caffino.

Hasil penelitian ini bertentangan dengan penelitian Isyanto et al., (2020) yang menyatakan citra merek berpengaruh secara parsial terhadap niat beli konsumen. Kemudian Cynthiadewi \& Hatammimi, (2014) menyatakan Citra merek dan E-wom berpengaruh positif dan signifikan terhadap niat beli. Begitu juga Rumokoy et al., (2016) menyatakan bahwa Citra merek, iklan, dan presepsi harga berpengaruh signifikan terhadap niat beli konsumen

\section{Pengaruh Citra Merek terhadap Sikap Pada Merek Kopi Caffino}

Berdasarkan hasil path analisis yang telah dilakukan, penelitian ini menunjukkan bahwa variabel citra merek berpengaruh positif signifikan terhadap variabel sikap konsumen terhadap merek Kopi Caffino. Hal tersebut menunjukkan semakin baik citra merek yang ditunjukkan oleh Kopi Caffino maka akan semakin baik pula sikap konsumen terhadap Kopi Caffino. Berdasarkan hasil tersebut maka hipotesis keempat diterima. Citra merek kopi Caffino yang menjadi slogan dari kopi Caffino sendiri yaitu \#BeAuthentic karena kopi Caffino dibuat dengan kopi dan susu asli. Hal tersebut dapat membentuk sikap yang positif dan membuat kopi Caffino lebih mudah diingat oleh konsumen, selanjutnya konsumen akan timbul sikap menyukai dan sikap memilih Caffino dibanding dengan merek kopi lain.

Hasil penelitian ini sesuai dengan penelitian Aghekyan-Simonian et al., (2012) yang menunjukkan Sikap terhadap merek dapat dipengaruhi oleh citra merek dari suatu produk, Semakin disukai citra merek, maka semakin positif sikap terhadap produk bermerek dan atributnya. Kemdian Elseidi \& ElBaz, (2016) mengemukakan citra merek berpengaruh kuat terhadap sikap konsumen terhadap merek tertentu. Begitu juga dengan Ain \& Ratnasari, (2015) yang menunjukkan citra merek berpengaruh positif dan signifikan terhadap sikap konsumen terhadap merek

\section{Pengaruh Sikap Terhadap Merek terhadap Niat Beli Kopi Caffino}

Berdasarkan hasil path analisis yang telah dilakukan, penelitian ini menunjukkan bahwa variabel sikap terhadap merek berpengaruh positif signifikan terhadap niat beli konsumen kopi Caffino. Hal tersebut menunjukkan semakin baik sikap konsumen terhadap kopi Caffino maka akan semakin besar pula niat konsumen untuk membeli kopi Caffino. Berdasarkan hasil tersebut maka hipotesis kelima diterima. Sikap konsumen terhadap kopi Caffino terbilang cukup positif, dimana hasil survei penelitian menyatakan sebagian konsumen mudah mengingat merek kopi Caffino. Hal tersebut dapat memengaruhi perilaku konsumen terhadap suatu produk yang mana dapat memotivasi calon konsumen untuk membeli kopi Caffino.

Hasil penelitian ini sesuai dengan penelitian Ha \& Lam, (2017), niat beli dipengaruhi secara kuat dan positif oleh sikap konsumen terhadap merek. Kemudian Vidyanata \& Hadiwidjojo, (2018) menyatakan sikap konsumen terhadap merek secara signifikan memiliki pengaruh positif terhadap niat membeli. Selain itu Singh \& Banerjee, (2018) menunjukkan adanya hubungan positif antara sikap terhadap merek dan niat beli, sehingga sikap terhadap merek meningkatkan niat beli di kalangan konsumen karena motivasi mereka meningkat. 


\section{KESIMPULAN}

Penelitian ini membuktikan bahwa adanya pengaruh positif dan signifikan antara celebrity endorsement terhadap niat beli konsuemen kopi Caffino. Tetapi untuk citra merek tidak berpengaruh signifikan terhadap niat beli konsumen kopi Caffino. Kemudian, celebrity endorsement terbukti memengaruhi secara langsung dan signifikan terhadap sikap konsumen terhadap merek kopi Caffino. Begitu juga dengan citra merek Caffino yang memiliki efek positif dan signifikan terhadap sikap konsumen terhadap merek kopi Caffino. Dengan demikian, penelitian ini menunjukkan pentingnnya celebrity endorsement, citra merek, dan sikap terhadap merek dalam membentuk niat beli konsumen. Sikap terhadap merek juga dapat meningkatkan niat pembelian konsumen.

Penelitian ini memiliki keterbatasan dalam hal penyebaran angket yang dilakukan secara online melalui direct massage Twitter dan Instagram yang dirasa kurang efisien, karena masih banyak responden yang mengetahui kopi Caffino namun tidak pernah melihat iklan kopi Caffino yang dibintangi oleh Iqbaal Ramadhan, sehingga mereka tidak dapat mengisi kuesionernya. Kemudian kekurangan dalam penelitian ini yaitu tidak dapat mengetahui alasan responden ketika membeli kopi Caffino dikarenakan penelitian ini hanya mengukur niat membelinya saja dan tidak semua responden pernah membeli kopi Caffino. Penelitian selanjutnya diharapkan dapat meneruskan dan mengembangkan penelitian ini pada masa yang akan datang, melalui penelitian yang lebih mendalam seperti mengukur tentang keputusan pembelian kopi Caffino atau bahkan mengukur tentang niat membeli ulang kopi Caffino, dan juga dapat meneliti lebih lanjut tentang citra merek dari suatu produk yang telah lama berdiri dibandingkan dengan produk yang baru berdiri dalam memengaruhi niat membeli konsumen.

Caffino diharapkan dapat memertahankan Iqbaal Ramadhan sebagai selebriti pendukung mereknya, hal tersebut dikarenakan penggemar Iqbaal Ramadhan yang cukup banyak dan kredibilitas yang dimiliki Iqbaal Ramadhan sudah cukup baik sehingga dapat memengaruhi calon konsumen untuk membeli kopi Caffino. Caffino juga diharapkan dapat menambah selebriti pendukung mereknya yang memiliki kredibilitas yang sama atau bahkan lebih baik dari selebriti sebelumnya, hal tersebut bertujuan untuk memerluas target pasar sasarannya dan membuat Caffino lebih banyak dikenal di Indonesia. Kemudian Caffino perlu juga untuk meningkatkan citra mereknya agar presepsi konsumen terhadap Caffino semakin baik pula.

\section{DAFTAR PUSTAKA}

Aghekyan-Simonian, M., Forsythe, S., Suk Kwon, W., \& Chattaraman, V. (2012). The role of product brand image and online store image on perceived risks and online purchase intentions for apparel. Journal of Retailing and Consumer Services, 19(3). 325-331. https://doi.org/https://doi.org/10.1016/j.jretconser.2012.03.006

Ain, N., \& Ratnasari, R. T. (2015). Pengaruh Brand Image Melalui Sikap Konsumen Terhadap Niat Beli Ulang Pada Produk Busana Muslim Zoyadi Surabaya. Jurnal Ekonomi Syariah Teori dan Terapan (JESTT), 2(7). 553-569.

Apejoye, A. (2013). Influence of Celebrity Endorsement of Advertisement on Students' Purchase Intention. Journal of Mass Communication \& Journalism, 03(03). https://doi.org/10.4172/2165-7912.1000152

Caffino.id. (2019). PT Sumber Kopi Prima Resmi Luncurkan Brand Caffino. (https://caffino.id/ptsumber-kopi-prima-resmi-luncurkan-brand-caffino/. Diakses pada 15 Maret 2021)

Cynthiadewi, P. R., \& Hatammimi, J. (2014). The Influence of Electronic Word Of Mouth Toward Brand Image and Purchase Intention of 13th Shoes, International Conference on Economics, Education and Humanities (ICEEH'14). https://doi.org/10.15242/icehm.ed1214001 
Mirza Dwi Darmawan \& Sri Setyo Iriani. Pengaruh Celebrity Endorsment dan Citra Merek terhadap Niat Beli Kopi Caffino melalui Sikap terhadap Merek

Elseidi, R. I., \& El-Baz, D. (2016). Electronic word of mouth effects on consumers' brand attitudes, brand image. International Conference on Restructuring of the Global Economy (ROGE), University of Oxford, UK, 7(5), 268-276.

Ferrinadewi. (2008). Merek dan Psikologi Konsumen. Edisi Pertama. Yogyakarta: Graha Ilmu.

Franciosa, J., Sondang, Y., Si, S., Sc, M., Pemasaran, P. M., Petra, U. K., \& Siwalankerto, J. (2014). Pengaruh Perceived Quality Tehradap Attitude Toward Brand Pada Pengguna Smartphone Samsung Di Surabaya. Jurnal Manajemen Pemasaran Petra, 2(1), 1-7.

Ghani, U., \& Kakakhel, T. (2011). The Impact of Celebrity Endorsement on the Youth of Pakistan. International Conference on Business and Economics Research, 16, 79-83

Gupta, R., Kishore, N., \& Verma, D. (2015). Celebrity Endorsements in Advertising: Impact on Consumers' Perception, Attitude and Purchase Intention. Australian Journal of Business and Management Research New South Wales Research Centre Australia (NSWRCA), 05(03), 1-15. https://www.academia.edu/21166019/Impact_Of_Celebrity_Endorsements_On_Consumers_Pu rchase_Intention_A_Study_of_Indian_Consumers

Ha, N. M., \& Lam, N. H. (2017). The Effects of Celebrity Endorsement on Customer's Attitude Toward Brand and Purchase Intention. International Journal of Economics and Finance; 9(1), 64-77. https://doi.org/10.5539/ijef.v9n1p64

Hanjani, G. A., \& Widodo, A. (2019). Consumer Purchase Intention: The Effect of Green Brand and Green Knowledge on Indonesian Nestle Company. Jurnal Sekretaris \& Administrasi Bisnis, $3(1), 39-50$.

Isyanto, P., Sapitri, R. G., \& Sinaga, O. (2020). Micro influencers marketing and brand image to purchase intention of cosmetic products focallure. Systematic Reviews in Pharmacy, 11(1), 601-605. https://doi.org/10.5530/srp.2020.1.75

Jamil, R. A., \& Hassan, S. R. ul. (2014). Influence of Celebrity Endorsement on consumer purchase intention for existing products: a comparative study. Journal of Management Info, 1(4), 1-8. https://doi.org/10.31580/jmi.v4i1.18

John C. Mowen, Michael Minor. (2002). Perilaku Konsumen (Jilid 1), Edisi Kelima, Jakarta: Erlangga.

Keller K. L. (1998). Building, Measuring, and Managing Brand Equity. New Jersey: Prentice Hall.

Keller, Kevin Lane. (2013). Strategic Brand Management: Building, Measuring, and Managing Brand Equity. Global Edition Pearson.

Koththagoda, K. C., \& Weerasiri, S. (2015). Celebrity Endorsement and Purchase Intention of Telecommunication Industry in Sri Lanka. International Journal of Science and Research, 6(6), 635-638. https://doi.org/10.21275/30051703

Lukitaningsih, A. (2013). Iklan Yang Efektif Sebagai Strategi Komunikasi Pemasaran. Jurnal Ekonomi Dan Kewirausahaan, 13(2), 116-129. http://ejurnal.unisri.ac.id/index.php/Ekonomi/article/view/670/576

McCracken, G. (1989). Who Is the Celebrity Endorser? Cultural Foundations of the Endorsement Process. Journal of Consumer Research, 16(3), 310-321. https://doi.org/10.1086/209217

Osei-Frimpong, K., Donkor, G., \& Owusu-Frimpong, N. (2019). The Impact of Celebrity 
Endorsement on Consumer Purchase Intention: An Emerging Market Perspective. Journal of Marketing Theory and Practice, 27(1), 103-121. https://doi.org/10.1080/10696679.2018.1534070

Phelps, J. E., \& Hoy, M. G. (1996). The Aad-Ab-PI relationship in children: The impact of brand familiarity and measurement timing. Psychology \& Marketing, 13(1), 77-105. https://doi.org/10.1002/(SICI)1520-6793(199601)13:1<77::AID-MAR5>3.0.CO;2-M

Restanti, F., Kusumawati, A., \& Devita, L. (2019). Pengaruh Celebrity Endorser Dan Electronic Word of Mouth Terhadap Minat Beli dan Dampaknya Terhadap Keputusan Pembelian. Jurnal $\begin{array}{llll}\text { Administrasi Bisnis } & \text { (JAB), } & \text { 68(1), }\end{array}$ http://administrasibisnis.studentjournal.ub.ac.id/index.php/jab/article/view/2796

Rumokoy, F., Pangemanan, S., \& Manorek, S. (2016). The Influence of Brand Image, Advertising,perceived Price Toward Consumer Purchase Intention at Samsung Smartphone. Jurnal Riset Ekonomi, Manajemen, Bisnis Dan Akuntansi, 3(4), 661-670

Schiffman, L. G., \& Kanuk, L. L. (2000). Consumer behaviour (7th ed.). Prentice Hall. https://doi.org/10.4135/9781446280096.n12.

Shimp, Terence. (2007). Periklanan Promosi (Aspek Tambahan Komunikasi Pemasaran Terpadu). Jilid I, edisi Terjemahan, Jakarta : Erlangga.

Singh, R. P., \& Banerjee, N. (2018). Exploring the influence of celebrity credibility on brand attitude, advertisement attitude and purchase intention. Global Business Review, 19(6), 1622-1639. https://doi.org/10.1177/0972150918794974

Solomon, R. S. (2011). Consumer Behavior, Buying, Having, and Being, 9th Edition, Boston: Pearson

Spears, N., \& Singh, S. (2004). Measuring Attitudes Toward The Brand And Purchase Intentions. Journal of Current Issues And Research in Advertising, 53-66.

Stephanie, E., Rumambi, L. J., \& Kunto, Y. S. (2013). Analisa Pengaruh Rio Dewanto Dan Donita Sebagai Celebrity Endorser Terhadap Minat Beli Produk Axe Anarchy Dengan Daya Tarik Iklan dan Efek Iklan Sebagai Variabel Intervening. Jurnal Manajemen Pemasaran Petra, 1(2), $1-9$.

Surachman S. (2008). Dasar-Dasar Manajemen Merek. Malang: Bayumedia Publishing: hal13

Topbrand-award.com. (2021). No Title. (https://www.topbrand-award.com/top-brandindex/?tbi_year=2021. Diakses pada 20 Maret 2021)

Vidyanata, D., \& Hadiwidjojo, S. D. (2018). the Role of Brand Attitude and Brand Credibility As a Mediator of the Celebrity Endorsement Strategy To Generate Purchase Intention. Jurnal Aplikasi Manajemen, 16(3), 402-411. https://doi.org/10.21776/ub.jam.2018.016.03.04

Vien, C., Yun, C., \& Fai, P. (2017). The Effect of Celebrity Endorsement on Brand Attitude and Purchase Intention. Journal of Global Business and Social Entrepreneurship (GBSE), 1(4), 141-150.

Wang, Y., \& Tsai, C. (2014). The Relationship between Brand Image and Purchase Intention: Evidence from Award Winning Mutual Funds. The International Journal of Business and Finance Research, 8(2), 27-40. 